\title{
Challenges Faced by Devolved Governance in Quality Service Delivery: A Case Study of Turkana Central Sub-county, Turkana County, Kenya
}

\author{
Mr James K. Sirite \\ Mount Kenya University, Lodwar Campus, Kenya \\ Dr Henry Ongori (Corresponding author) \\ Lecturer Mount Kenya University, Lodwar Campus, Kenya \\ E-mail: henrymireri@gmail.com \\ Mr Darius Bosire \\ Lecturer Mount Kenya University, Lodwar Campus, Kenya
}

Received: September 5, 2017 Accepted: December 14, 2017 Published: December 27, 2017 doi:10.5296/ijld.v7i4.12374

URL: https://doi.org/10.5296/ijld.v7i4.12374

\begin{abstract}
The purpose of this study was to identify the challenges faced in quality service delivery to Turkana Central Sub-county citizens of Turkana County. The study used cross-sectional survey design. The sample size selected for the study was 261. Data was collected using questionnaires and interview guides. Data was analyzed by descriptive statistics and presented in tables and figures for ease interpretation. The major findings of the study show that devolved governance faces some challenges. For instance the devolved governance is faced with corruption, lack of transparency and accountability and inadequate funds. This adversely affects quality service delivery to its citizens. The findings of the study would inspire policy makers at the county and national government level to come up with appropriate strategies to mitigate the challenges identified in order to improve the quality of services offered by the county governments.
\end{abstract}

Keywords: governance, government, national county, devolution, benefits and challenges 


\section{Introduction}

Devolution has become a key global trend over the recent decades as many states have decentralized power to sub-state governments. In United Kingdom (UK) devolution has led to radical decentralization of powers to local governments. There are a number of benefits from decentralizing government. Decentralization promotes greater experimentation, better matching of services to local preferences and greater competition between the service providers of government funded services. Functions transferred to the local level include environmental policy, working aid welfare delivery, education and health, housing and planning, lifestyle regulation and natural resource exploitation. This is confirms that fiscal decentralization is associated with higher national income and higher levels of investments. In particular, increasing the local taxation from five percent $(5 \%)$ to twenty percent $(20 \%)$; increases Gross Domestic Product (GDP) per capita by six percent (6\%). Higher levels of revenue associated with decentralization, the UK is particularly in a good position to gain in transferring powers from central government to local government (Booth, 2015).

In Africa, centralized systems of government have been blamed for hindering efficient delivery of public services. However, in Rwanda there is notable progress since the start of decentralization process in 2000. Local governments have enjoyed unprecedented range of competencies and resources. In order to understand the paradoxical nature of Rwandan decentralization, the process is disaggregated into three dimensions; administrative, financial and political. This demonstrates that in all these dimensions, decentralization is characterized by the promotion of good controls, good governance, and technocratic and depoliticized local government activities (Good fellow, 2014).

In Kenya devolution is anchored in the constitution of 2010.The main purpose is to bring government closer to the people. This approach of putting county governments at the centre of dispersing political power and economic resources to Kenyans at the grassroots is one of the interventions of taking services closer to the people. Furthermore, the promulgation of the New Constitution in $27^{\text {th }}$ August 2010 marked a major milestone in the way in which the country is governed. Thus the political power and economic resources are moved away from the central government to county government. As a result, 47 county governments and the senate were established following the March $4^{\text {th }} 2013$ elections as part of the implementation of devolution.

Therefore, the objective of the study is to identify the challenges faced in providing public service delivery by devolved governance units within Turkana central sub-county, Turkana County.

\section{Literature Review and Conceptual Framework}

Decentralization occurs when national government shares some of its power and resources with other groups or particularly those that are either geographically dispersed, or are responsible for specific functions, or are given jurisdiction over specified physical locations. The key elements to note in decentralization are power, authority and responsibilities which are diffused intentionally to peripheral units from the centre to achieve predetermined objectives. Litvack (1988) defines decentralization as the "assignment of fiscal, political and 
administrative responsibilities to lower levels of government". Fiscal, political and administrative instruments are used to achieve the transfer of responsibility to other levels of government. These are the instruments which gave rise of fiscal, political and administrative decentralization (Mawhood, 2008).

\section{Challenges faced in Quality Public Service Delivery}

Previous studies (McCloughlin \& Batley, 2012) tends to be fairly generic in terms of political and governance constraints. For instance, concepts like 'political will' or the existence of 'weak incentives' are often referred to but rarely further developed in terms of specific institutional and governance arrangement that contribute to such bottlenecks or gaps.

Furthermore developing countries have identified dysfunctional relationships between the citizens, service delivery organizations and politicians which are the way of demand responsive services. This therefore makes the service users to have low levels of awareness of performance of politicians in relations to services entitled to them. This is evident in regions where politicians try to compete for votes by their history of favouring particular groups in service delivery allocations (McCourt and Keefer. 2007). However there are criticisms that persist of inefficiency and patronage or outright corruption in provision of public services. Some of the most committed advocates of increased aid such as Gates Foundation have also been the most impatient in the seeming inability of public agencies to play their part in delivering millennium development goals promises and have preferred setting up non-state structures to deliver their programmes (Garret, 2007).

World Development report (2004) posits that the quality of public services in many countries is particularly low or poor. Thus common manifestations of poor service delivery across the world are long waiting time, limited attention, differential treatment and high absence rate. In in addition in Malawi there is weak public goods and service delivery due to lack of priority setting and poor decision making, rather than resource scarcity per se. Furthermore, scarcity of funding, leads to the low uptake of good ideas and insufficient capacity are result of poor planning and policy incoherence, prioritization of alternative agendas such as winning elections and appointing big cabinets, rent seeking that diverts funds out of productive use to waste. All these lead to uncoordinated action which brings about poor service delivery to the people (Cammack, 2011). Moral hazard constraints also seem to particularly shape form of organizational accountability. In terms of resource allocation, they allow the state or delivery organizations to under invest in key areas for example, where aid resources are assumed to act as substitutes.

Local governments operate within this constrained economic environment. The challenge for local authorities is to strike a balance between demands for sustained first world levels of service and affordability. To do this, devolved units are looking at their modes of service delivery verses costs. Furthermore, public services mostly account for a large proportion of government budgets but still increasing spending has not often been matched with improvement in outcomes. In the worst case, public service can be bedeviled by corruption which leads to money intended for books, teachers, dispensaries, medical supplies and infrastructure being siphoned off by officials or private contractors. In the world, children still 


\section{Macrothink}

International Journal of Learning and Development

ISSN 2164-4063

2017, Vol. 7, No. 4

leave school while they are unable to read and do basic arithmetic. The quality of health care also remains uneven. This therefore means that increasing resources, equipment, finance and personnel does not guarantee the quality of education or health care .This is due to lack of integrity, transparency and accountability. Even where the integrity and public resource flows can be secured, approaches to public service delivery is designed in a way to respond to the present day needs driven by complex challenges such as those created by aging population, chronic health conditions, mega cities and property inequality. Quality in service is therefore critical (World Bank, 2004).

Lack of access to information by the public and translating information to action are major challenges. The relationship between citizens, policy makers, programme managers and service providers are complicated and are not easily altered through a single intervention. For instance, in Uganda formal information sources are not seen as influential and citizen are often either too afraid to act or do not consider it a responsibility or they do not know what to do (Ringold, Holla, Koziol and Srinivassan, 2012).

Lack of control systems and improper use of new technology which will safeguard against abuse, misuse, fraud and irregularities to inefficient cash management, collusive practices in the procurement are weaknesses identified in the internal control and audit systems. Many public financial management systems do not produce information in a timely manner for the people to keep track of service delivery expenditures. This might be due to use of poor technical systems, lack of technological know-how or delays in conducting the audits and making the results available to the public (Baltaci and Yilmaz, 2006); Craig, Deshingkar and Start, 2005).

\section{Conceptual Framework}

The conceptual framework consists of independent variable and dependent variable. The independent variable consists of challenges faced by devolved governance while dependent variable includes services offered by devolved government. The moderating variable includes the constitution of Kenya as shown in Figure 1. 


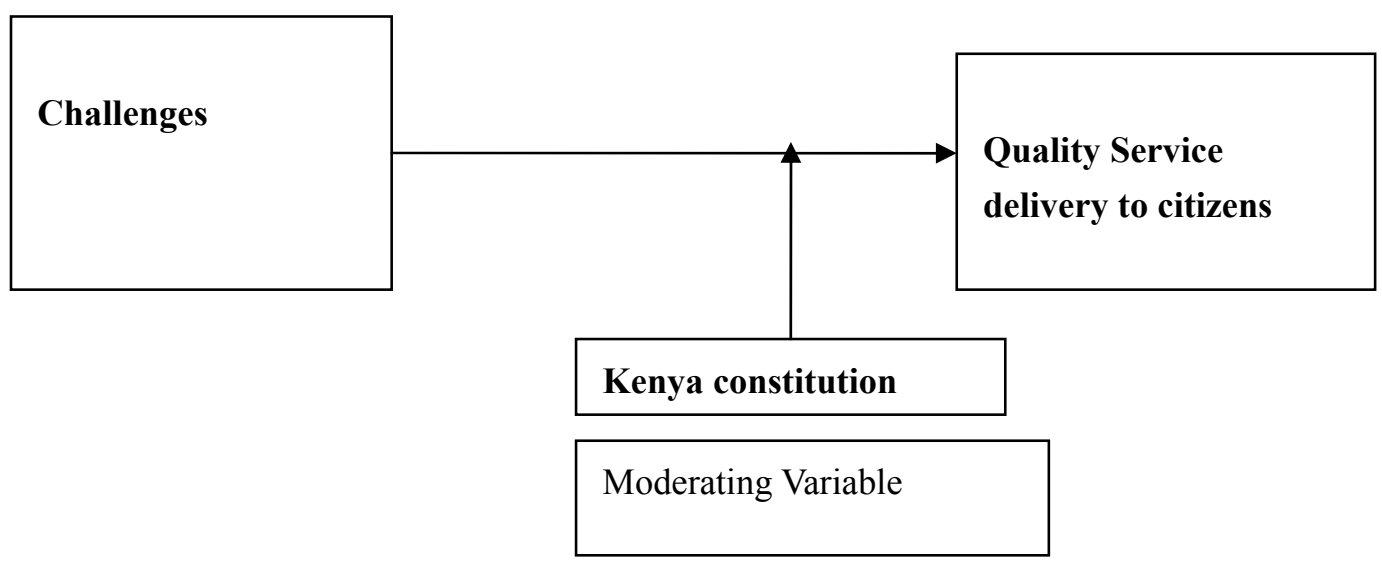

Figure 1. Conceptual Framework

Source: Author 2016.

\section{Research Methodology}

The research design adopted in this study was the descriptive research design. Descriptive design is a method of collecting information by interviewing or administering questionnaires to a sample of study for extensive research. The survey instrument used in this study was a questionnaire. Thus the questionnaire comprised of closed and open ended questions. The questionnaire was used because it allows the researcher to reach out to a large number of respondents within a short time and provides adequate time to the respondents to respond to the items in the survey instrument (Owens, 2002, Saunders et al 2007, Welman et al, 2008 and Creswell, 2003). Furthermore, the questionnaire was divided into two parts. Part 1 captured items related to the demographics of respondents and Part 2 comprised questions related to challenges faced by the county government in service delivery. The items in the instruments were measured by 5 point Likert point scale. The Content validity of the research instrument was done by getting the opinion of expert's on the subject matter. Data collected was analysed by use of computer software Statistical Package for Social Sciences (SPSS version 21). Thereafter, data was tabulated into tables and figures for ease interpretation.

\section{Results and Discussion}

\subsection{Response Rate}

Two hundred and eighty (280) questionnaires were distributed to the sample of the study. However, two hundred and sixty one (261) were duly completed and returned. Therefore, the response rate was $93.2 \%$. Thus the response rate is a reliable to warrant analysis and 


\section{Macrothink}

International Journal of Learning and Development

generalization of findings.

\subsection{Demographics of Respondents}

The demographic of respondents described includes gender, age, marital status, education level and occupation of the respondents.

\subsection{Age of Respondents}

The results on the age of respondents are presented in Table 1. Age of respondents' forms a vital characteristic in understanding their perceptions about the particular problems.

Table 1. Age of Respondents

\begin{tabular}{ll}
\hline Age cohort & Percentage \\
\hline 20 Years and below & 6.1 \\
$20-35$ Years & 47.2 \\
$36-45$ Years & 21.8 \\
$45-55$ Years & 15.7 \\
Above 56 & 9.2 \\
\hline
\end{tabular}

The results indicate that majority of respondents were between the age cohort of 20-35 years $123(47.1 \%)$, followed by those between $36-45$ years, $57(21.8 \%$ ) then those between $45-55$ years of age $41(15.7 \%)$. The minority constituted those who were 56 years and above $16(6.1 \%)$ and those who were 20 years and below were $24(9.2 \%)$. Therefore most participants were between age cohorts of $20-45$ which accounted for $69 \%$ of the respondents.

\subsection{Gender of Respondents}

The results of the gender of respondents are shown in Figure 1. The findings revealed that majority of the respondents were males 157 (60.2\%) while the females were 104 (39.8\%). This implies that there was inclusivity in the study and therefore, the representation of both genders reduces the chances of biasness in the study. 


\section{Macrothink}

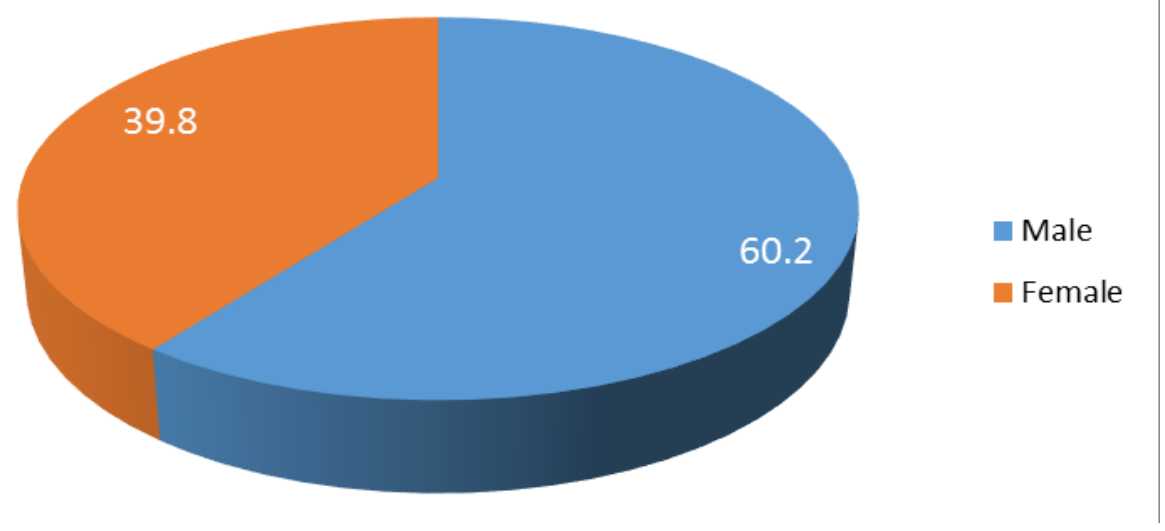

Figure 1. Gender of Respondents

\subsection{Marital Status}

The findings of the marital status of the respondents are shown in figure 2 . The results shows that most of the respondents were married, 170(65.1\%), followed by those who were single, $59(22.6 \%)$. The minority included $16(6.1 \%)$ who were divorcées and $15(5.7 \%)$ who had separated. Nonetheless, $1(0.5 \%)$ did not give any response in regard to their marital status. This implies that most respondents in the region were married and would give mature responses.

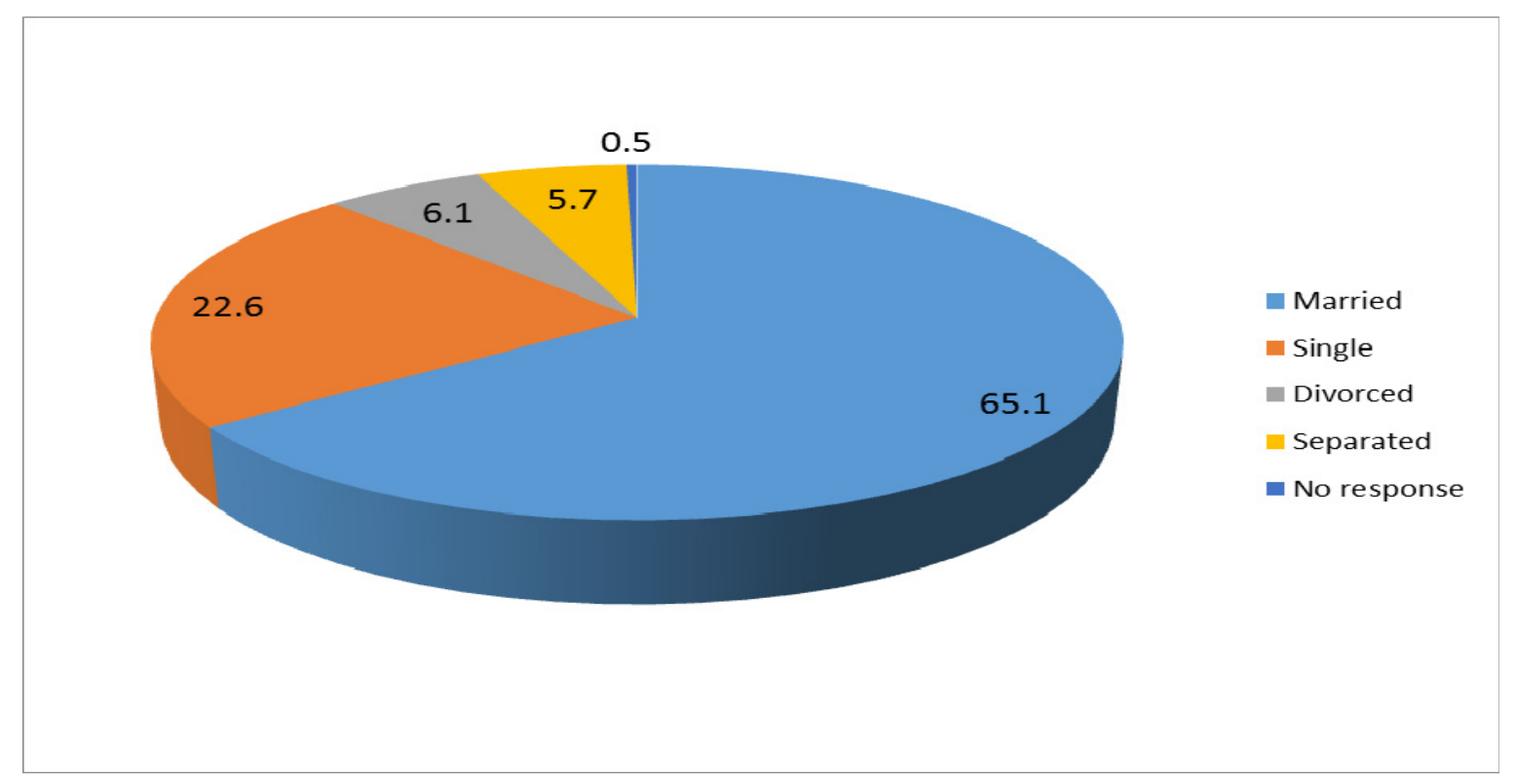

Figure 2. Marital Status

\subsection{Level of Education of Respondents}

The results of the level of education are presented in figure 3. It is evident from the study that 


\section{Macrothink}

International Journal of Learning and Development

ISSN 2164-4063 2017, Vol. 7, No. 4

most respondents were primary certificate holders 184(70.6\%). Others had diploma, $39(14.9 \%)$, degree $21(8.0 \%)$ and O-level/None, 12(4.6\%). A very small number had post graduate degree, $5(1.9 \%)$ and they formed the minority. Therefore, most participants who took part in the study had not attained the higher education levels which are so important today to create knowledge based society.

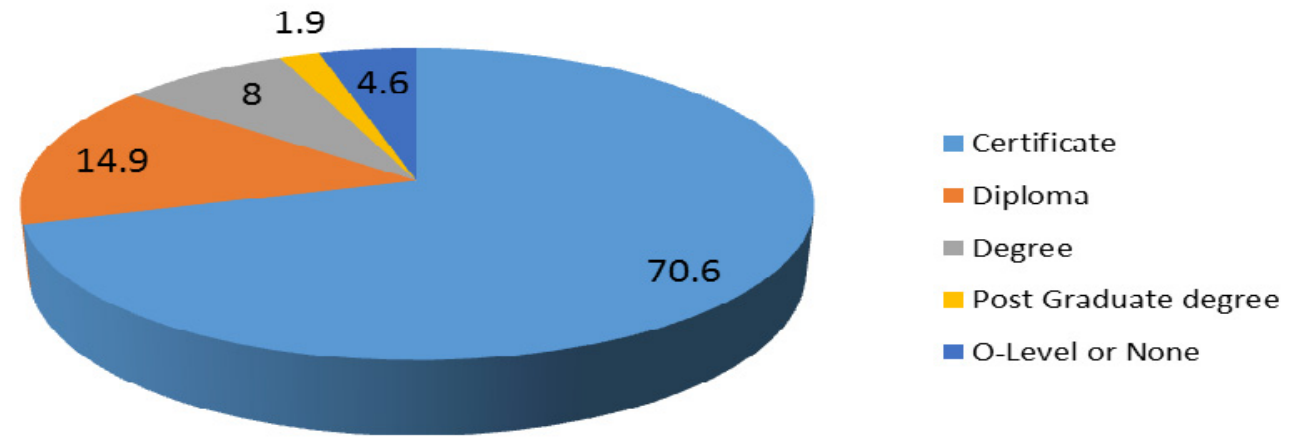

Figure 3. level of Education of Respondents

\subsection{Occupation of Respondents}

The results on the occupation of respondents are shown in Figure 4. The results indicate that a bigger number of the respondents did not disclose their occupation 134(51.3\%). Nevertheless, $65(24.9 \%)$ were opinion leaders, 36(13.8\%) were religious leaders, $17(6.5 \%)$ were administrators and $9(3.5 \%)$ were politicians.

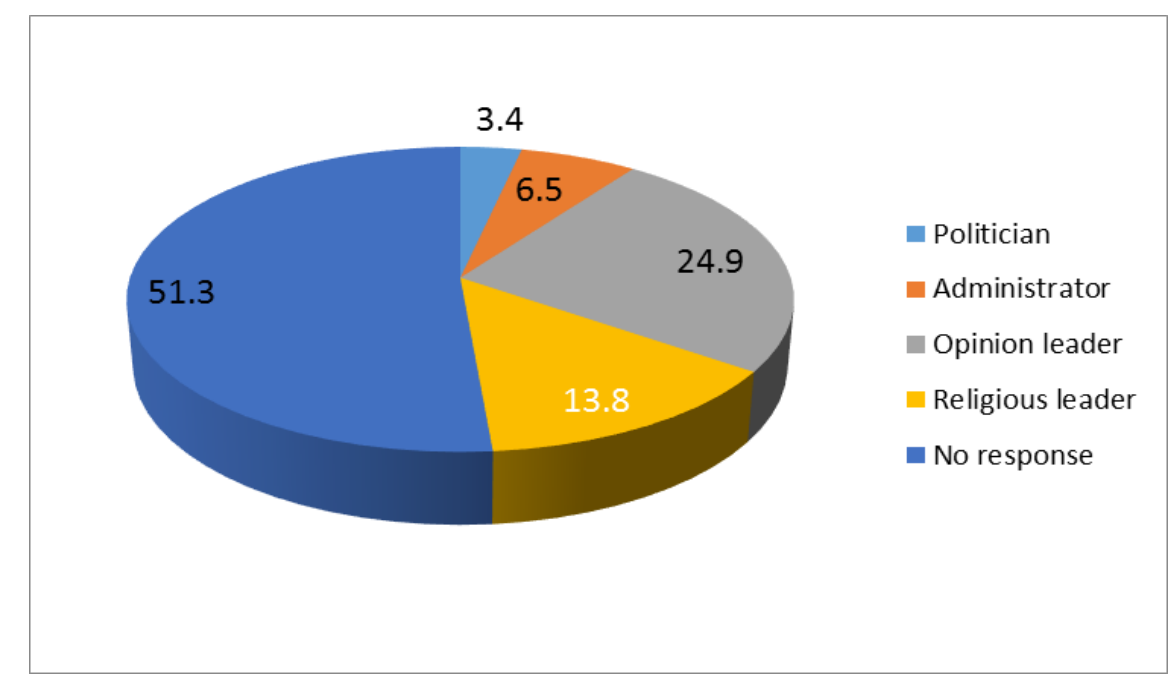

Figure 4. Occupation of Respondents 


\section{Challenges faced in Quality Public Services delivery}

The results on the challenges faced by the county in providing public service delivery to its citizens are presented in Table 2.

Table 2. Result on challenges faced in provision of quality public services

\begin{tabular}{llllllllllll}
\hline \multirow{2}{*}{ Items } & \multicolumn{1}{l}{ Frequencies and Percentages } & & & & & \\
\cline { 2 - 12 } & $\mathbf{5}$ & & $\mathbf{4}$ & & $\mathbf{3}$ & & $\mathbf{2}$ & & $\mathbf{1}$ & \\
& $\mathrm{No}$ & $\%$ & $\mathrm{~N}$ & $\%$ & $\mathrm{~N}$ & $\%$ & $\mathrm{~N}$ & $\%$ & $\mathrm{~N}$ & $\%$ \\
\hline Reduced public revenue & 59 & 22.6 & 71 & 27.2 & 53 & 20.3 & 36 & 13.8 & 42 & 16.1 \\
Demographic changes & 50 & 19.2 & 73 & 28.0 & 82 & 31.4 & 29 & 11.1 & 27 & 10.3 \\
Increased County debts & 46 & 17.6 & 39 & 14.9 & 91 & 34.9 & 33 & 12.7 & 52 & 19.9 \\
Lack access to information & 55 & 21.1 & 96 & 36.8 & 28 & 10.7 & 43 & 16.5 & 39 & 14.9 \\
Transparency \& accountability & 103 & 39.5 & 73 & 28.0 & 20 & 7.7 & 19 & 7.3 & 46 & 17.5 \\
Piecemeal transfer of functions & 45 & 17.2 & 82 & 31.4 & 78 & 29.9 & 22 & 8.5 & 34 & 13.0 \\
corruption & 113 & 43.3 & 80 & 30.7 & 18 & 6.9 & 16 & 6.1 & 34 & 13.0 \\
Lack of funds & 70 & 26.8 & 63 & 24.1 & 47 & 18.0 & 42 & 16.2 & 39 & 14.9 \\
Failure to use ICT & 50 & 19.1 & 73 & 28.0 & 49 & 18.8 & 39 & 14.9 & 50 & 19.2 \\
Lack of political goodwill & 71 & 27.2 & 87 & 33.3 & 44 & 16.9 & 24 & 9.2 & 35 & 13.4 \\
Inadequate infrastructure & 82 & 31.4 & 88 & 33.7 & 21 & 8.1 & 35 & 13.4 & 35 & 13.4 \\
Lack of skilled manpower & 73 & 28.0 & 89 & 34.1 & 29 & 11.1 & 40 & 15.3 & 30 & 11.5 \\
Delay disbursement funds & 71 & 27.2 & 93 & 35.6 & 40 & 15.3 & 22 & 8.5 & 35 & 13.4 \\
Coordination problems & 64 & 24.5 & 86 & 33.0 & 53 & 20.3 & 23 & 8.8 & 35 & 13.4 \\
Chronic health conditions & 65 & 24.9 & 61 & 23.4 & 50 & 19.2 & 35 & 13.4 & 50 & 19.2 \\
Marginalization of groups & 65 & 24.9 & 75 & 28.7 & 43 & 16.5 & 42 & 16.1 & 36 & 13.8 \\
Recall elected representatives & 53 & 20.3 & 71 & 27.2 & 59 & 22.6 & 43 & 16.5 & 35 & 13.4 \\
poor quality services & 66 & 25.3 & 65 & 24.9 & 28 & 10.8 & 51 & 19.5 & 51 & 19.5 \\
\hline
\end{tabular}

$5=$ Strongly Agree to; 1 =strongly disagree.

Reduced public revenue is one of the challenges experienced in Turkana Central, the results showed that, 59(22.6\%) strongly agreed, 71(27.2\%) agreed, 53(20.3\%) were not certain, $36(13.8 \%)$ disagreed and $42(16.1 \%)$ who strongly disagreed. Majority of the participants acknowledged that the reduction of public revenue has increased due to poor systems of tax collection. Demographic change was also cited as a challenge in quality public service delivery. The results shows that 50(19.2\%) strongly agreed, 73(28.0\%) agreed, 82(31.4\%) were not sure, $29(11.1 \%$ ) disagreed, while $27(10.3 \%)$ strongly disagreed. A good number agreed that this challenge has really hindered quality service delivery. Thus, where the population is bigger than the economic activities accruing, quality of service delivery is compromised.

Increased county debts was also analyzed and findings shows that 46(17.6\%) strongly agreed, $39(14.9 \%)$ agreed, 91(34.9\%) not sure, 33(12.6\%) disagreed, while 52(19.9\%) strongly disagreed. Majority of the respondents $91(34.9 \%)$ were not sure whether there was increased 
county debts in their county. Lack of access to information was also cited as one of the challenges faced in service delivery. The results shows that, 55(21.1\%) strongly agreed, 96(36.8\%) agreed, 28(10.7\%) were unsure, 43(16.5\%) disagreed, 37(14.2\%) strongly disagreed. Most respondent's consents that lack of information contributed to poor quality public services.

Lack of transparency \& accountability is one of the challenge faced in quality service delivery, 103(39.5\%) strongly agreed, 73(28.0\%) agreed, 20(7.7\%) were not sure, 19(7.3\%) disagreed, while $45(17.2 \%)$ strongly disagreed. Most participants concurred with the idea that lack of transparency and accountability hinders quality service delivery. Piecemeal transfer of functions to counties is also considered as a challenge to quality public service delivery. The results shows that $45(17.2 \%)$ of the respondents strongly agreed, $82(31.4 \%)$ agreed, $78(29.9 \%)$ were not sure, $22(8.4 \%)$ disagreed, while 34(13.0\%) strongly disagreed. Therefore, slow transfers of functions to the county delays in service delivery to the citizens. Corruption being another factor was also examined and results indicates that, 113(43.3\%) strongly agreed, $80(30.7 \%)$ agreed, $18(6.9 \%)$ were not sure, 16(6.1\%) disagreed, while 34(13.0\%) strongly disagreed. Majority confirmed that increased corruption was a major factor that causes poor service delivery in the counties. This has been observed in the recent years that counties in Kenya who have reported high cases of corruption are the poor performing counties which mean that quality of service delivery is compromised. Lack of funds is a challenge in service delivery. Findings shows that, 70(26.8\%) strongly agreed, 63(24.1\%) agreed, 47(18.0\%) were not sure, $42(16.1 \%)$ disagreed and 39(14.9\%) strongly disagreed. Lack of fund in counties may be as a result of delayed county revenue allocations from the National government which in turn affects the delivery of services at the county level thus poor quality of services.

The world at large has been reduced to a global community due to technological advancement and in particular, use of information communication technology. Counties in its plans have not been left out, the introduction of integrated financial management information systems (IFMIS) with the core function of overseeing the implementation of a unified financial management system. The IFMIS contributes to improvement of transparency and accountability. Therefore, failure to use ICT in Turkana Central sub-county county was assessed and findings show that, $50(19.2 \%)$ strongly agree, $73(28.0 \%)$ agreed, 49(18.8\%) were unsure, 39(14.9\%) disagreed while $50(19.2 \%)$ strongly disagreed. Most participants agreed that ICT is not in use which means service delivery is poor. On Lack of political goodwill, 71(27.2\%) strongly agreed, $87(33.3 \%)$ agreed, 44(16.9\%) were uncertain, 24(9.2\%) disagreed, while 35(13.4\%) strongly disagreed. It is evident that many respondents were uncertain regarding lack of political goodwill.

Infrastructure is the backbone of any country's economy. Analysis on whether Inadequate infrastructure affects quality of service delivery the study revealed that, $82(31.4 \%)$ strongly agreed, 88(33.7\%) agreed, 21(8.0\%) were not sure, 35(13.4\%) disagreed; while 35(13.4\%) strongly disagreed. The analysis depicted that most respondents approved that there was inadequate infrastructure in Turkana Central Sub-County. Lack of skilled manpower constitutes another challenge in the provision of quality service. The results shows that $73(28.0 \%)$ of respondents strongly agreed, 89(34.1\%) agreed, 29(11.1\%) were not sure, 
40(15.3\%) disagreed, while 30(11.5\%) strongly disagreed. Therefore most respondents agreed that skilled manpower is a problem in the region which translates to poor quality of service.

Another challenge examined was the delay in disbursement of funds to counties. This then highlighted that, $71(27.2 \%)$ strongly agreed that it was actually a challenge in the quality of service deliver, 93(35.6\%) agreed, 40(15.3\%) not sure, 22(8.4\%) disagreed and 35(13.4\%) strongly agreed. counties depend on revenue from the national government in order to fund its projects at the county level. When these funds are delayed then service delivery gets affected also. In regards to the respondents majority concurred that delay in disbursement of funds poses as a challenge to service delivery. On the other hand, lack of coordination between governments has really posed a big a challenge to quality of service in the sub county and the participants had varying responses. 64(24.5\%) strongly agreed, 86(33.0\%) agreed, 53(20.3\%) were not sure, $23(8.8 \%)$ disagreed while $35(13.4 \%)$ had no response on this. Most participants concurred with the fact that lack of coordination between governments affects the quality of service delivery. Generally coordination is part of administrative function and where two factions exist such as the national government and the county government coordination must be in place for proper delivery of public duty as mandated by the constitution. On whether the recall of elected representatives is a challenge showed that, 53(20.3\%) of the respondents strongly agreed, $71(27.2 \%)$ agreed, 59(22.6\%) were not sure, 43(16.5\%) disagreed, 32(12.3\%) strongly disagreed while $3(1.1 \%)$ had no response. Majorities were in support of this with few other not sure and some disagreed on the same.

\section{Discussion of Results}

The objective of the study was to identify the challenges to quality public service delivery by devolved governance units within Turkana central sub-county. The results identified the key challenges that faced the Turkana County Government in implementing quality public service delivery as corruption (74\%) lack of transparency and accountability $(67.5 \%)$, and inadequate infrastructure $(65.1 \%)$.

Corruption and lack of transparency \& accountability were cited as major challenges to the provision of quality service. Another notable challenge was piecemeal transfer of functions to counties. The national government has not transferred all functions which were supposed to be devolved to county governments. In some instances, the functions which are devolved and money allocated to these functions is inadequate. Agustin (2005) asserts that transparency ensures that information is available that can be used to measure the authorities' performance and guard against any possible misuse of power. Therefore, transparency serves to achieve accountability, which means that authorities can be held responsible for their actions. The other notable challenge was lack of skilled manpower that is required to provide quality service. The county governments continues to recruit and train human resources and the process hasn't been complete since some of the essential staff are yet to be recruited meaning gaps in service delivery in those understaffed sectors.

Occasional standoffs due to poor coordination between the national and county governments posed a challenge to quality of service in the sub county. These findings are similar to Warmers, (2003) who found out that successful decentralization requires administrative and financial 
capacity and effective citizen participation, but many rural governments lack an adequate revenue base or sufficient professional management capacity.

\section{Conclusion and Recommendations of the Study}

However, the devolved governance has some challenges. For instance, there is Corruption, lack of transparency and accountability. This affects service delivery to the residents of Turkana Central Sub County. Piecemeal transfer of function has compounded the problem with inadequate funds and poor revenue collection hampers quality service delivery. Huge public debts also consume large money that could otherwise be used for providing essential services to its citizens.

\section{Recommendations}

The recommendations of the study have been informed by the research findings and conclusions of the study. Thus the recommendations of the study are as follows:

- The Turkana county government should automate its revenue collection systems to ensure that enough revenue is collected to facilitate development in the Sub County and Turkana County in general.

- Public participation forums should be held regularly and encourage participatory monitoring and evaluation quality delivery and improvement

- The county government should work closely with the Ethics and Anti-Corruption Commission to ensure that those who misuse public funds are held accountable.

- The national Treasury should speed up the transfer of funds to County governments so that services are not hampered.

- The county government should train their employees on aspects of corruption and accountability. These will go along addressing on the negative effect of corruption in orgnisation.

- Employees of the county should be encouraged to attend seminars or workshops which deal with understanding the importance of devolved governance. There is need for employees working in the county to provide quality services to their citizens without asking any favors. Management should ensure that employees are taken for refreshers courses to acquire news skills in order to cope with any changes in the organisation.

- The Non-Government Organisations (NGOs) especially those funding or giving grants to counties should ensure that funds disbursed are utilized for the purpose requested. In addition, they should monitor the implementation process in projects funded by them. These would enhance high degree of accountability and transparency.

- High institutions of learning should develop short term courses which are tailored to the needs of counties especially on the issues of corruption and accountability. This will assist management and employees of the counties on the effects of corruption in 


\section{Macrothink}

organisations.

- Training consultants must always do training needs assessment to ensure that the knowledge and skills imparted to county management and employees are in line with changes in organisation and are critical in the sustainability and growth of county governments.

\section{Recommendations for Further Research}

There is need for further research to be undertaken to do a comparative analysis in other sub counties within Turkana County and also other Counties in Kenya to ascertain the impact of devolution after its implementation. Thus a detailed citizen's perception survey could be conducted to ascertain the level of satisfaction by citizens on service delivery in their counties. Further research should also be carried out to ascertain on whether Kenyans could wish to see more functions devolved or returned to the national government.

\section{References}

Ali, M. (2011). Southern Sudan Case Study: State building, peace building and service Delivery in fragile and conflict affected states. London; Practical Action/Save the Children.

Baltaci, M., \& Yilmaz, S. (2006). Keeping an eye on sub-national governments, internal control audit at local levels. World Bank Institute working paper 37257, Washington DC.

Besley, T. and Burgess, R., (2002). The political economy of government responsiveness: Theory and evidence. Quarterly Journal of Economics, 117(4), 1415-1451. https://doi.org/10.1162/003355302320935061

Booth, P. (2015). English votes for English laws. No solution to problem caused by Devolution: Institute of Economic Affairs.

Burugu J. N. (2010). Understanding Devolution Governance in Kenya: Centre for Leadership, Education and Development (CLEAD).

Cammack, D. (2011). Local Governance and Public Goods in Malawi. IDS Bulletin, 42, 43-52. https://doi.org/10.1111/j.1759-5436.2011.00210.x

Craig, J., Deshingker, P., \& Start, D. (2005): Grounding the state devolution development in India's Panchayats. Journal of Development Studies, 41(6), 937-70. https://doi.org/10.1080/00220380500155197

Creswell, J. W. (2009). Research Design: Qualitative, Quantitative and mixed methods approaches. Los Angeles: Sage.

Crosby, P. (2008). Service Quality is Free (8th ed.). McGraw-Hill Publishers, New York.

Demmke, C. (2006). Decentralisation of Human Resource Practices-European Comparative Perspective: EGPA Conference, Milan. 


\section{Macrothink Institute ${ }^{\text {TM }}$}

Dheret, C. (2011). Put the Well being at the Heart of Public services. Retrieved January, 2011, from http//www. publicserviceeurope.com/article/690

Gallagher, M., \& Mitchell, P. (2005). The politics of electoral systems. Oxford University Press. https://doi.org/10.1093/0199257566.001.0001

Garret, L. (2007). The challenge of global health: Beware what you wish for. Foreign Affairs, 86(1), 14-38.

Gebauer, H. (2008). Dynamic Theory of service management.

GOK. (2010). The Constitution of Kenya, Government Printer.

GOK. (2012). The County Government Act, Government Printer.

Goodfellow, T. (2014) Rwanda's Political Settlement and the Urban Transition: Expropriation, Construction and Taxation in Kigali. Journal of East African Studies, 8(2). https://doi.org/10.1080/17531055.2014.891714

McCourt, W. (2007). Impartiality through bureaucracy: A Srilankan approach to managing values. Journal of international development, 19, 429-42. https://doi.org/10.1002/jid.1372

Mugenda, A. (2008). Social Science Research Methodology (2nd ed.). ACTS Press Nairobi.

Ndegwa, N. (2002). Decentralization in Africa: A stop taking survey: Africa working.

Orodho, A. J. (2003). Essentials of Educational and Social Sciences Research Method. Nairobi: Masola Publishers.

Oso, W. Y., \& Onen, D. (2009). A General Guide to writing Research Proposal and Report: A handbook of beginning Researchers. Jomo Kenyatta Foundation, Nairobi.

Ringold, D., Holla, A., Koziol, M., \& Srinivasan, S. (2012). Citizen and Service Delivery: Assessing the use of social accountability approaches in Human Development. Washington DC, World Bank.

Saunders, M., Lewis, P., \& Thornhill, A. (2007). Research Methods for Business Students. Fourth Edition: Oxford.

Schindler, L. (2013). Social Research Process (8th ed.). McGraw-Hill Publishers New York.

Pattern, A. (2010). Quantitative Research The Constitution of Kenya. The Kenyan Laws: Government Press.

Treisman, D. (2007). Causes of Corruption. Journal of Public Economics, 76(3).

Welman, C., Kruger, F., \& Mitchell, B. (2008). Research Methodology: Business and Economics (3rd ed.). Research and Development Oxford University Press, South Africa,

Amadi, H. (2009). Kenya's Grant Coalition government: Another obstacle to urgent Constitutional reform. African Spectrum, 44(3), 149-164. 
Azfar, Ch. O., Kahokonen, S., Lanyi, A., Meagher, P., \& Rutherford, D. (2004). Decentralization, governance and public services.

Barret, C. B., Mude, A. G., \& Omiti, J. M. (2007). Decentralization and the Social Economics of Development. Lessons from Kenya. Nairobi: CAB international

Barkan, J. D., \& Chege, M. (1989). Decentralizing the State: District Focus and the Politics of Reallocation in Kenya. The Journal of Modern African Studies, 27(3), 431-453. https://doi.org/10.1017/S0022278X00020371

Lankina, T. (2008). Cross cutting review on the drivers of local council accountability and performance: Social development working paper No 112. World Bank, Washington DC.

Larry, D. (2004). Why Decentralize Power in Democracy; Presented to the Conference on Fiscal and Administrative Decentralization. Baghdad, February 12, 2004

Lim, J. H. (2010): Empowering citizen voices in the era of e-government; implications from South Korean cases. Theoretical and Empirical researches in Urban Management, 7(6), 19-31.

Lubembe, E. (2013). Perspectives of the Public Service in Kenya (1st ed.). Twawesa Publications, Nairobi Kenya. Design, 10th Edition, McGraw-Hill Publishers, New York.

Smith, L. (2009). Explaining violence after recent elections in Kenya and Ethiopia: African studies programme. Edmund A Walsh School of Foreign Service, Georgetown University, Washington DC, USA, 16(5), 867-897. https://doi.org/10.1080/13510340903162085

\section{Copyright Disclaimer}

Copyright for this article is retained by the author(s), with first publication rights granted to the journal.

This is an open-access article distributed under the terms and conditions of the Creative Commons Attribution license (http://creativecommons.org/licenses/by/4.0/). 